\title{
OBSERVASI PENGGUNAAN POSISI HIGH FOWLER PADA PASIEN EFUSI PLEURA DI RUANG PERAWATAN PENYAKIT DALAM FRESIA 2 RSUP DR.HASAN SADIKIN BANDUNG : STUDI KASUS
}

\author{
Alvian Pristy Windiramadhan ${ }^{*}$, Asha Grace Sicilia², Eka Afirmasari ${ }^{3}$, Sri Hartati, \\ Hesty Platini ${ }^{5}$, Hamidah ${ }^{6}$ \\ 1,2,3,4,5 Fakultas Keperawatan, Universitas Padjajaran, Bandung, Indonesia \\ ${ }^{6}$ RSUP Dr. Hasan Sadikin, Bandung, Indonesia \\ E-mail:*mr.ianramadhan@gmail.com
}

\begin{abstract}
Abstrak
Efusi pleura merupkaan penimbunan cairan yang berlebihan pada rongga pleura sehingga menyebabkan seseorang mengalami sesak nafas. Tindakan yang dapat dilakukan untuk mengurangi sesak nafas dan meningkatkan oksigenasi agar tidak ketergantungan dengan pemberian oksigen dalam jangka panjang yaitu dengan posisi high fowler. Oleh karena itu peneliti tertarik untuk melakukan studi kasus tentang penggunaan posisi high fowler pada pasien efusi pleura di Ruang Fresia 2 RSUP Dr.Hasan Sadikin Bandung. Penelitian dilakukan dengan pendekatan studi kasus pada 3 orang pasien dengan krieria pasien yang di diagnosis efusi pleura pasien yang mengalami sesak nafas (RR > 24 x/menit), pasien dewasa atau lanjut, pasien dapat berkomunikasi dan bersedia diwawancara, terpasang CTT atau pigtail dan terpasang oksigen. Setelah dilakukan observasi selama tiga hari ada perbedaan nilai pernafasan dan saturasi oksigen sebelum dan sesudah posisi high fowler. Rentang nilai pernafasan sebelum posisi high fowler adalah 24 - 30 kali/menit dengan nilai saturasi oksigen 97 - 98\%. Sedangkan rentang nilai pernafasan sesudah posisi high fowler adalah 22 - 27 kali/menit dengan nilai saturasi oksigen 98-99\%. Posisi high fowler merupakan posisi pilihan untuk pasien yang mengalami sesak nafas khususnya pada pasien yang mengalami efusi pleura.
\end{abstract}

Kata kunci: efusi pleura ; posisi high fowler; sesak nafas; studi kasus;

\begin{abstract}
Observation of Using High Fowler Position in Pleura Efficient Patients in The Medical Ward in Fresia 2 Dr. Hasan Sadikin Bandung Hospital: Case Study. Pleural effusion is an excessive accumulation of fluid in the pleural cavity and causing a person to experience shortness of breath. Actions that can be taken to reduce shortness of breath and increase oxygenation so as not to depend on the provision of oxygen in the long term is by positioning high fowler. Therefore researchers interested in conducting a case study of the use of high fowler positions in pleural effusion patients in Fresia Room 2 Dr.Hasan Sadikin Hospital Bandung. The study was conducted with a case study approach on 3 patients with patients who were diagnosed with pleural effusion of patients experiencing shortness of breath $(R R>24 x / \mathrm{min})$, adult or advanced patients, patients can communicate and be willing to be interviewed, CTT or pigtail attached and attached oxygen. After observing for three days there were differences in respiratory values and oxygen saturation before and after the high fowler position. The range of respiratory values before the high fowler position is 24-30 times / minute with an oxygen saturation value of 97-98\%. While the range of respiratory values after the high fowler position is 22-27 times / minute with an oxygen saturation value of $98-99 \%$. The high fowler position is the position of choice for patients who experience shortness of breath, especially in patients who experience pleural effusion.
\end{abstract}

Keywords : case study; dyspnea; pleural effusion ; positioning high fowler 


\section{Pendahuluan}

Efusi pleura merupkaan penimbunan cairan dalam rongga pleura, akibat jenis cairan yang transudat, eksudat, atau darah yang berlebihan pada rongga pleura. Di Amerika Serikat, setiap tahunnya terjadi 1,5 juta kasus efusi pleura. Sementara pada populasi umum secara internasional diperkirakan setiap 1 juta orang, 3000 orang terdiagnosis efusi pleura. Di negara-negara berat, efusi pleura terutama disebabkan oleh gagal jantung kongestif, sirosis hati, keganasan, dan pneumonia bakteri. Di negara sedang berkembang seperti Indonesia, lazim diakibatkan oleh infeksi tuberkulosis. (Puspita, Soleha, \& Berta, 2015).

Keadaan yang dapat disebabkan efusi pleura antara lain penyakit infeksi, sistemik, keganasan, obat-obatan, trauma, dan setelah tindakan operasi. Dengan berbagai keluhan utama penderita seperti sesak napas, batuk tidak produktif, dan lainnya. Pada penderita efusi pleura keluhan semakin meningkat saat aktivitas, hal ini tergantung dari tingkatan lesinya (Nasution \& Widirahardjo, 2018).

Upaya untuk menurunkan angka kematian akibat sistem pernapasan memerlukan penangan yang mendasar. Penanganan dasar yang diperlukan berupa pengamatan pada penderita sesak nafas berupa peningkatan usaha napas melalui peningkatan $\mathrm{RR}$ dan penggunaan otot-otot bantu pernapasan guna memenuhi deman doksigen di dalam tubuh. Salah satu tindakan keperawatan yang penting adalah positioning yang bertujuan untuk meningkatkan ekspansi paru sehingga mengurangi sesak (Dean, 2014).

Pemilihan posisi untuk penderita dengan masalah pernapasan sangat penting untuk memfasilitasi pernapasan yang adekuat. Terdapat berbagai macam posisi tidur mulai dari supine, pronasi, lateral dan fowler. Posisi fowler merupakan posisi pilihan untuk orang yang mengalami kesulitan pernapasan (Kozier, 2011). Oleh karena itu pemilihan posisi yang tepat sangat menentukan keberhasilan intervensi keperawatan yang dilakukan.

Terdapat berbagai penelitian dan studi yang membahas tentang penggunaan posisi untuk mengatasi berbagai masalah pernapasan pada pasien dengan bermacammacam kasus di luar negeri. Penelitian Moaty, Mokadem dan Elhy (2017) tentang efek posisi fowler terhadap oksigenasi dan status hemodinamik pada pasien dengan cedera kepala menunjukan bahwa posisi semi fowler dengan elevasi $30^{\circ}$ memiliki dampak positif terhadap pernapasan dengan hasil terjadinya peningkatan $\mathrm{PaO} 2, \mathrm{SaO} 2$, dan $\mathrm{RR}$ serta penurunan $\mathrm{PaCO} 2$.

Safitri dan Andriyani (2008) menyatakan saat terjadi sesak nafas penderita biasanya tidak dapat tidur dengan posisi berbaring, melainkan harus dalam posisi duduk atau setengah duduk untuk meningkatkan ekspansi paru sehingga oksigen lebih mudah untuk masuk ke paru dan pola napas kembali optimal. Tindakan yang dapat dilakukan untuk meningkatkan oksigenasi, agar tidak ketergantungan dengan pemberian oksigen dalam jangka panjang yaitu dengan positioning high fowler. Posisi high fowler adalah posisi dimana tempat tidur di posisikan dengan ketinggian $60-90^{\circ}$ bagian lutut tidak di tinggikan.. Kemiringan menggunakan gravitasi membantu mengembangkan dada dan mengurangi tekanan abdomen dan diafragma. Pada saat gravitasi terjadi akan menarik diafragma ke bawah serta memungkinkan ekspansi dada dan ventilasi paru yang lebih besar. Posisi ini dibantu penopang sandaran yang sering digunakan dua bantal yang diletakkan di punggung dan kepala (Kozier dkk, 2011).

Tujuan tindakan pemberian posisi yang efektif pada penderita sesak nafas adalah untuk menurunkan konsumsi $\mathrm{O} 2$ dan ekspansi paru yang maksimal, serta mempertahankan kenyamanan. Kestabilan pola napas ditandai dengan pemeriksaan fisik berupa frekuensi pernapasan yang normal, tidak terjadi ketidakcukupan oksigen (hipoksia), 
perubahan pola napas dan obstruksi jalan napas (Kozier dkk, 2011).

Berdasarkan hasil observasi diruang Fresia 2 RSUP Dr.Hasan Sadikin Bandung, tindakan position high fowler merupakan tindakan yang sudah di terapkan pada pasien yang mengalami sesak nafas. Oleh karena itu peneliti tertarik untuk melakukan studi kasus tentang penggunaan posisi high fowler pada pasien efusi pleura di Ruang Fresia 2 RSUP Dr.Hasan Sadikin Bandung.

\section{Metode Penelitian}

Metode penelitian yang digunakan adalah rancangan penelitian studi kasus. Studi kasus merupakan rancangan penelitian yang mencakup pengkajian satu unit penelitian secara intensif misal klien, keluarga, kelompok, komunitas atau institusi. Rancangan dari suatu studi kasus bergantung pada keadaan kasus namun tetap mempertimbangkan faktor penelitian waktu. Keuntungan yang paling besar dari rancangan ini adalah pengkajian secara terperinci meskipun jumlah responden sedikit, sehingga akan didapatkan gambaran unit subjek secara jelas (Nursalam, 2016).

Studi kasus ini bertujuan untuk memberikan gambaran tentang penggunaan posisi high fowler pada pasien efusi pleura di Ruang Fresia 2 RSUP Dr.Hasan Sadikin Bandung yang dilakukan selama tiga hari tanggal $25-27$ November 2019. Penelitian ini tidak menggunakan etik penelitian karena hanya melakukan observasi tanpa memberikan intervensi terhadap tindakan keperawatan yang sudah lazim dan sering digunakan diruangan. Penelitian dilakukan pada 3 orang pasien dengan krieria Pasien yang di diagnosis efusi pleura pasien yang mengalami sesak nafas (RR > 24 x/menit), pasien dewasa atau lanjut, pasien dapat berkomunikasi dan bersedia diwawancara, terpasang CTT atau pigtail dan terpasang oksigen .

\section{Hasil Penelitian \\ a. Pasien 1}

Ny. W, seorang perempuan berusia 50 tahun yang mengalami efusi pleura bagian dextra. Pasien di diagnosis Tumor paru dextra T4N2M1 dengan metastase pleura dan para neoplastis. Pasien mengalami sesak nafas sejak 4 bulan yang lalu disertai dengan batuk berdarah. Berdasarkan hasil wawancara pasien statusnya sudah menikah dan pendidikan terakhirnya SMP. Pasien merupakan ibu rumah tangga yang bekerja bersama dengan suaminya dirumah membuka usaha warung kelontong. Pasien seorang perokok pasif, dimana suaminya adalah seorang perokok aktif yang menghabiskan 2 bungkus rokok perhari.

Berdasarkan hasil pengkajian di dapatkan, pasien mengalami dispnea tingkat III, kesaadarn composmentis E4M6V5, pasien tampak lemah, TD: $120 / 80 \mathrm{mmHg}$, RR : 28x/menit, HR: 86x/menit, S: $36,1^{\circ} \mathrm{C}$, BB 47, kepala dan wajah tidak ada sianosisis, mukosa bibir lembab, leher tidak ada pembesaran kelenjar tiroid, terpasang pigtail pada daerah ICS $\mathrm{V}$ posterior bagian dextra dan dengan mengelurkan cairan pleura sebanyak $270 \mathrm{cc}$ berwarna merah dengan cara dilakukan aspirasi dengan menggunakan spuit. pengembangan dada kanan sama dengan kiri, vokal fremitus raba kanan < kiri, suara perkusi sonor/dullness ICS II, III, ICS V, VI, suara auskultasi vesikuler/vesikuler yang menurun ICS II, III, ICS V, VI, ekstremitas terpasang infus $\mathrm{NaCl} \quad 0,9 \% \quad 20$ tpm di tangan sebelah kanan, dan terpasang oksigen $2 \mathrm{~L} /$ menit

Hasil pemeriksaan penunjang pemeriksaan cairan pleura tanggal 20 November 2019 di dapatkan LDH cairan pleura $832 \mathrm{U} / \mathrm{L}$, albumin cairan pleura 2100 $\mathrm{mg} / \mathrm{dl}$, protein cairan pleura $4930 \mathrm{mg} / \mathrm{dl}$, glukosa cairan pleura $11 \mathrm{mg} / \mathrm{dl}$, rivalta: positif, warna: merah, kejernihan: keruh, jumlah sel 1802 sel/uL PMN 16\%, MN 84\%. Preparat BTA tidak ditemukan. Sedangkan hasil pemeriksaan hematologi tanggal 20 November 2019 didapatkan hemoglobin 8,5 
g/dl, hamtokrit 26,7 \%, leukosit 10,88 $10^{\wedge} 3 / \mathrm{uL}$, eritrosit $4,15 \mathrm{juta} / \mathrm{uL}$, trombosit 395 ribu/uL, MCV 64,3 fL, MCH 20,5 pg, MCHC $31,8 \%$, basofil 0 , eosinofil 1 , neutrofil batang 0 , netrofil segmen 79 , limfosit 12 , monosit 8 , PT 1 detik, PT 10,40 detik, INR 1, INR 0,92, APTT 1 detik, APTT 26,10 detik, glukosa sewaktu $77 \mathrm{mg} / \mathrm{dL}$, ureum 26,0 $\mathrm{mg} / \mathrm{dL}$, kreatinin 0,59 mg/dL, kalium 4,6mEq/L.

Program Terapi yang didapat antara lain oksigen nasal kanul 2 liter/menit, diet Tinggi kalori Tinggi Protein (TKTP), ceftadizime 26g/6jam, ciprofoloxacin 400mg/6jam, ketorolac 1 g/6jam, omeprazole 40mg/24jam, $\mathrm{N}$-asetilsistein $200 \mathrm{mg} / 12 \mathrm{jam}$, codein 20mg 1 tab/8jam, $\mathrm{NaCl}$ 0,9\% 20 tpm.

Berdasarkan hasil wawancara pasien mengatakan sesaknya bertambah apabila dengan posisi tidur berbaring dan sesaknya berkurang apabila dengan posisi setengah duduk. Akan tetapi, terasa nyeri pada daerah yang terpasang pigtail sehingga pasien lebih nyaman dengan posisi tidur high fowler.

\section{b. Pasien 2}

Tn. F, laki-laki berusia 25 tahun yang mengalami efusi pleura massif bagian sinistra. Pasien di diagnosis mengalami CAP, squamous cell carcinoma sinistra stadium IV dan metastatis pleura pericardium. Sebelum sakit, pasien bekerja sebagai karyawan di sebuah pabrik. Pasien mulai merasa sesak sejak 9 bulan yang lalu. Pasien merupakan seorang perokok aktif dengan menghabiskan rokok 1 setengah sampai dengan 2 bungkus perhari. Pasien mulai merokok sejak berusia 14 tahun dan masih duduk dibangku SMP. Pasien bekerja sebegai buruh pabrik dan statusnya belum menikah. Pendidikan terakhir SMA.

Berdasarkan hasil pengkajian di dapatkan saat ini masih mengeluh sesak nafas, derajat dispnea tingkat IV, kesadaran composmentis E4M6V5, BB :62 Kg, TD: 110/70 mmHg, RR : 32x/menit, HR: $92 \mathrm{x} / \mathrm{menit}, \mathrm{S}: 36,3^{\circ} \mathrm{C}$, kepala dan wajah tidak ada sianosis, mukosa bibir lembab, leher tidak ada pembesaran kelenjar tiroid, pengembangan dada kanan sama dengan kiri, vokal fremitus raba kiri < kanan, suara perkusi sonor ICS II, III, ICS V, VI, auskultasi terdengar ronhi, Ekstremitas: terpasang infus $\mathrm{NaCl}$ 0,9\% 20 tpm di sebelah tangan kiri., dan terpasang oksigen $2 \mathrm{~L} /$ menit. Pasien saat ini terpasang CTT pada ICS V posterior bagian sinistra dan terpasang draignase. Cairan pleura yang dikeluarkan sebanyak $340 \mathrm{cc} / \mathrm{hari}$.

Hasil pemeriksaan penunjang, pemeriksaan cairan pleura tanggal 15 November 2019 di dapatkan LDH cairan pleura 339 U/L, albumin cairan pleura 1900 $\mathrm{mg} / \mathrm{dl}$, protein cairan pleura $3740 \mathrm{mg} / \mathrm{dl}$, glukosa cairan pleura $92 \mathrm{mg} / \mathrm{dl}$, rivalta: positif, warna: merah, kejernihan: keruh, jumlah sel $184 \mathrm{sel} / \mathrm{uL}$ PMN 65\%, MN 35\%. Preparat BTA tidak ditemukan. Sedangkan hasil pemeriksaan hematologi tanggal 25 November 2019 didapatkan hemoglobin 8,5 g/dl, hamtokrit 27,4 \%, leukosit 7,04 10^3/uL, eritrosit 2,90 juta/uL, trombosit $234 \mathrm{ribu} / \mathrm{uL}$, MCV 94,5 fL, MCH 29,3 pg, MCHC 31,0 \%, basofil 0 , eosinofil 1, neutrofil batang3, netrofil segmen 71 , limfosit 11 , monosit 14 , albumin 2,10 g/dL.

Program Terapi yang didapat antara lain oksigen nasal kanul 2 liter/menit, diet Tinggi kalori Tinggi Protein (TKTP), ceftadizime 26g/6jam, ciprofoloxacin 400mg/6jam, ketorolac $1 \mathrm{~g} / 6 \mathrm{jam}$, omeprazole $40 \mathrm{mg} / 24 \mathrm{jam}$, paracetamol $500 \mathrm{mg} / 6 \mathrm{jam}, \mathrm{N}$-asetilsistein 200 $\mathrm{mg} / 12 \mathrm{jam}$, codein 20mg $1 \mathrm{tab} / 8 \mathrm{jam}, \mathrm{NaCl}$ $0,9 \% 20$ tpm.

Berdasarkan hasil wawancara, pasien mengatakan sesaknya bertambah apabila dengan posisi tidur terlentang dan sesaknya berkurang bila dengan posisi tidur fowler. Selain fowler pasien, juga merasa nyaman dengan posisi fowler bersamaan dengan lateral kiri. Hasil observasi setelah dilakukan tindakan posisi fowler RR pasien menurun menjadi $25 \mathrm{x} /$ menit.

\section{c. Pasien 3}

Pasien ketiga adalah Ny. K, seorang perempuan berusia 44 tahun yang mengalami efusi pleura dextra ec malignancy. Pasien di diagnosis mengalami Tumor mediastinum e.c 
lymphoma dd teratoma metastase KGB dan vena cava superior syndrome grade III. Pasien mengeluh sesak disertai batuk sejak 3 bulan yang lalu.Pasien merupakan seorang ibu rumah tangga, status sudah menikah dan pendidikan terkahir SMA. Pasien seorang perokok pasif, dimana suaminya adalah seorang perokok aktif yang menghabiskan 2 bungkus rokok perhari.

Pasien saat ini masih mengeluh sesak nafas. Sesaknya bertambah berat apabila pasien batuk dan melakukan aktivitas terlalu erat. Berdasarkan hasil pengkajian di dapatkan, kesadaran composmentis E4M6V5, derajat dispnea tingkat IV, BB $82 \mathrm{~kg}$, TD: 120/80 mmHg, RR : 28x/menit, HR: $88 \mathrm{x} / \mathrm{menit}$, S: $37,0^{\circ} \mathrm{C}$, kepala dan wajah tidak ada sianosis, mukosa bibir lembab, leher tidak ada pembesaran kelenjar tiroid, pengembangan dada kanan sama dengan kiri, palpasi vokal fremitus raba kanan < kiri , suara perkusi sonor ICS II, III, ICS V, VI, suara auskultasi ronhi, Ekstremitas terpasang infus $\mathrm{NaCl}$ 0,9\% 20 tpm di sebelah kaki sinistra dan terpasang oksigen dengan nasal canul $2 \mathrm{~L} / \mathrm{menit}$. Saat ini pasien terpasang pigtail pada ICS $\mathrm{V}$ posterior bagian dextra. Cairan pleura dikeluarkan dengan menggunakan spuit sebanyak $120 \mathrm{cc} /$ hari dan berwarna kuning keruh

Hasil pemeriksaan penunjang, pemeriksaan cairan pleura tanggal 19 November 2019 di dapatkan LDH cairan pleura $119 \mathrm{U} / \mathrm{L}$, albumin cairan pleura 2100 $\mathrm{mg} / \mathrm{dl}$, protein cairan pleura $4830 \mathrm{mg} / \mathrm{dl}$, glukosa cairan pleura $142 \mathrm{mg} / \mathrm{dl}$, rivalta: positif, warna: kuning, kejernihan: agak keruh, jumlah sel 214 sel/uL PMN 5\%, MN 95\%. Preparat BTA tidak ditemukan. Sedangkan hasil pemeriksaan hematologi tanggal 24 November 2019 didapatkan kadar hemoglobin 14,5 g/dl, hamtokrit 43,2 \%, leukosit 14,54 10^3/uL, eritrosit 4,91juta/uL, trombosit $346 \mathrm{ribu} / \mathrm{uL}, \mathrm{MCV} 88.0 \mathrm{fL}, \mathrm{MCH}$ 29,5 pg, MCHC33,6 \%.

Program Terapi yang didapat antara lain oksigen nasal kanul 2 liter/menit, diet Tinggi kalori Tinggi Protein (TKTP), ceftadizime 26g/6jam, ciprofoloxacin 400mg/6jam, ketorolac $1 \mathrm{~g} / 6 \mathrm{jam}$, omeprazole $40 \mathrm{mg} / 24 \mathrm{jam}$, $\mathrm{N}$-asetilsistein $200 \mathrm{mg} / 12 \mathrm{jam}$, codein $20 \mathrm{mg} 1$ tab/8jam NaCl 0,9\% 20 tpm.

Tabel 1

Demografi dan Status Kesehatan

\begin{tabular}{|c|c|c|c|c|}
\hline No & Data & Pasien I & Pasien II & Pasien III \\
\hline 1 & Jenis Kelamin & Perempuan & Laki-laki & Perempuan \\
\hline 2 & Diagnosa & $\begin{array}{l}\text { Efusi Pleura } \begin{array}{r}\text { Dextra, } \\
\text { Tumor paru dextra }\end{array} \\
\text { T4N2M1 } \\
\text { metastase pleura dan para } \\
\text { neoplastic }\end{array}$ & $\begin{array}{l}\text { Efusi Pleura massif } \\
\text { sinistra, CAP, squamous } \\
\text { cell carcinoma sinistra } \\
\text { stadium IV dan metastatis } \\
\text { pleura pericardium }\end{array}$ & $\begin{array}{l}\text { Efusi pleura dextra ec } \\
\text { malignancy, Tumor } \\
\text { mediastinum e.c } \\
\text { lymphoma dd teratoma } \\
\text { metastase KGB dan } \\
\text { vena cava superior } \\
\text { syndrome grade III }\end{array}$ \\
\hline 3 & Usia & 50 tahun & 25 tahun & 44 tahun \\
\hline 4 & Status & Menikah & Belum menikah & Menikah \\
\hline 5 & Pendidikan & SMP & SMA & SMA \\
\hline 6 & Lama Rawat & 7 Hari & 9 hari & 7 hari \\
\hline 7 & Durasi Penyakit & 4 Bulan & 9 bulan & 2 bulan \\
\hline 8 & $\mathrm{BB}$ & $47 \mathrm{~kg}$ & $62 \mathrm{~kg}$ & $82 \mathrm{~kg}$ \\
\hline 9 & Riwayat rokok & $\begin{array}{l}\text { Perokok pasif, suami } 2 \\
\text { bungkus per hari }\end{array}$ & $\begin{array}{l}\text { Perokok aktif, } 1 \text { setengah- } \\
2 \text { bungkus perhari }\end{array}$ & $\begin{array}{l}\text { Perokok pasief, suami } \\
\& \text { anak } 1-2 \text { bungkus } \\
\text { perhari }\end{array}$ \\
\hline \multirow[t]{3}{*}{10} & \multirow[t]{3}{*}{ Terapy } & \multirow{2}{*}{$\begin{array}{l}\text { Ciprofoloxacin } \\
\text { 400mg/6jam, ketorolac } \\
\text { 1g/6jam, omeprazole }\end{array}$} & $\begin{array}{l}\text { Ceftadizime } 26 \mathrm{~g} / 6 \mathrm{jam}, \\
\text { ciprofoloxacin }\end{array}$ & $\begin{array}{l}\text { Ciprofoloxacin } \\
\text { 400mg/6jam, ketorolac }\end{array}$ \\
\hline & & & 400mg/6jam, ketorolac & 1g/6jam, omeprazole \\
\hline & & $\begin{array}{l}40 \mathrm{mg} / 24 \mathrm{jam}, \\
\text { asetilsistein }\end{array}$ & $\begin{array}{lr}\text { 1 g/6jam, } & \text { omeprazole } \\
40 \mathrm{mg} / 24 \mathrm{jam}, & \mathrm{N}-\end{array}$ & 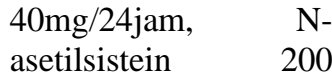 \\
\hline
\end{tabular}




\begin{tabular}{|c|c|c|c|c|}
\hline & & $\begin{array}{l}\mathrm{mg} / 12 \mathrm{jam} \text {, codein } 20 \mathrm{mg} 1 \\
\text { tab/8jam } \mathrm{NaCl} 0,9 \% 20 \\
\text { tpm, }\end{array}$ & $\begin{array}{lr}\text { asetilsistein } & 200 \\
\mathrm{mg} / 12 \mathrm{jam}, \mathrm{codein} & 20 \mathrm{mg} 1 \\
\mathrm{tab} / 8 \mathrm{jam}, \mathrm{NaCl} & 0,9 \% \quad 20\end{array}$ & $\begin{array}{l}\mathrm{mg} / 12 \mathrm{jam}, \quad \text { codein } \\
20 \mathrm{mg} 1 \mathrm{tab} / 8 \mathrm{jam} \mathrm{NaCl} \\
0,9 \% 20 \mathrm{tpm} .\end{array}$ \\
\hline 11 & $\begin{array}{l}\text { Rencana Tindak } \\
\text { lanjut }\end{array}$ & Radioterapy & $\begin{array}{l}\text { Radioterapy } \\
\text { Kemoterapy }\end{array}$ & Radioterapy \\
\hline
\end{tabular}

Tabel 2

Observasi status pernafasan dan saturasi oksigen pada posisi semi fowler dan fowler

\begin{tabular}{ccllll}
\hline No & Pasien & \multicolumn{1}{c}{ Data } & \multicolumn{1}{c}{ Hari 1 } & \multicolumn{1}{c}{ Hari 2 } & \multicolumn{1}{c}{ Hari 3 } \\
\hline 1 & Pasien 1 & RR sebelum posisi high fowler & $26 \mathrm{x} / \mathrm{menit}$ & $26 \mathrm{x} / \mathrm{menit}$ & $25 \mathrm{x} / \mathrm{menit}$ \\
& & SpO2 sebelum posisi high fowler & 97 & 98 & 98 \\
& & RR posisi sesudah fowler & $24 \mathrm{x} / \mathrm{menit}$ & $22 \mathrm{x} / \mathrm{menit}$ & $22 \mathrm{x} / \mathrm{menit}$ \\
& & SpO2 sesudah posisi fowler & 98 & 99 & 99 \\
2 & Pasien 2 & RR sebelum posisi high fowler & $30 \mathrm{x} / \mathrm{menit}$ & $28 \mathrm{x} / \mathrm{menit}$ & $28 \mathrm{x} / \mathrm{menit}$ \\
& & SpO2 sebelum posisi high fowler & 97 & 97 & 98 \\
& & RR posisi sesudah fowler & $27 \mathrm{x} / \mathrm{menit}$ & $25 \mathrm{x} / \mathrm{menit}$ & $24 \mathrm{x} / \mathrm{menit}$ \\
& & SpO2 sesudah posisi fowler & 97 & 98 & 98 \\
3 & Pasien 3 3 & RR sebelum posisi high fowler & $28 \mathrm{x} / \mathrm{menit}$ & $25 \mathrm{x} / \mathrm{menit}$ & $24 \mathrm{x} / \mathrm{menit}$ \\
& & SpO2 sebelum posisi high fowler & 96 & 98 & 98 \\
& & RR posis sesudahi fowler & $22 \mathrm{x} / \mathrm{menit}$ & $23 \mathrm{x} / \mathrm{menit}$ & $22 \mathrm{x} / \mathrm{menit}$ \\
& & SpO2 sesudah posisi fowler & 98 & 98 & 99 \\
\hline
\end{tabular}

\section{Pembahasan}

Pada pembahasan ini, peneliti menjelaskan tiga orang pasien efusi plura yang sudah ditentukan berdasarkan kriteria inklusi. Semua pasien dalam penelitian ini adalah pasien mengalami sesak nafas yang peneliti lakukan observasi nilai status pernafasan dan saturasi oksigen terhadap intervensi tindakan pengaturan positioning yang dilakukan oleh perawat diruangan untuk mengurangi sesak nafas. Observasi ini peneliti lakukan selama tiga hari berturutturut pada saat sebelum dan sesudah perawat mengatur posisi high fowler. Kemudian peneliti membandingkan hasil observasi nilai pernafasan dan saturasi oksigen pada tiga pasien tersebut dengan teori dan jurnal yang ada.

Secara demografi dua orang pasien berjenis kelamin perempuan dan satu orang lainnya adalah laki-laki. Rentang usia pasien dari 25 sampai dengan 50 tahun. Dua orang pasien statusnya sudah menikah, sedangkan satu orang pasien lainnya belum menikah. Berdasarkan tingkat pendidikannya, dua orang pasien pendidikan terakhirnya SMA dan satu orang SMP. Dari pekerjaanya, dua orang pasien bekerja sebagai ibu rumah tangga dan satu orang sebagai buruh pabrik.
Berdasarkan lama rawat, dua orang pasien dirawat pada hari ke tujuh dan satu orang dirawat pada hari ke Sembilan. Rentang durasi lamanya penyakit adalah dua sampai dengan Sembilan bulan. Rentang berat badan pasien adalah $47-82 \mathrm{~kg}$. Berdasarkan riwayat merokok, satu orang sebagai perokok aktif dengan banyaknya perhari adalah satu setengah sampai dengan dua bungkus rokok perhari, sedangkan dua orang lainnya adalah sebagai perokok pasif.

Semua pasien dalam studi kasus ini sudah terpasang CTT dan pigtail. Jumlah cairan pleura yang dikeluarkan saat aspirasi bervariasi antara 120 sampai dengan $270 \mathrm{cc} /$ hari. Berdasarkan hasil pemeriksaan cairan pleura, semua pasien mengalami efusi pleura di sebabkan oleh carcinoma atau malignasi. Di tandai dengan terdapatnya cairan efusi pleura yang berwarna merah dan kuning serta diagnose medis yang di tegakan dokter yaitu : Efusi Pleura Dextra Tumor paru dextra T4N2M1 dengan metastase pleura dan para neoplastic, Efusi Pleura massif sinistra, CAP, squamous cell carcinoma sinistra stadium IV dan metastatis pleura pericardium serta Efusi pleura dextra ec malignancy, Tumor mediastinum e.c lymphoma dd 
teratoma metastase $\mathrm{KGB}$ dan vena cava superior syndrome grade III.

Dari hasil observasi dan wawancara semua pasien mengeluh sesak nafas, batuk, bahkan ada satu pasien yang mengeluh batuk berdarah. Menurut McGrath, (2011) pada seseorang yang mengalami efusi pleura, gejala klinis dapat berupa keluhan sesak nafas, rasa berat pada dada, nyeri bisa timbul akibat efusi yang banyak berupa nyeri pleuritik atau nyeri tumpul yang terlokalisir, pada beberapa penderita dapat timbul batukbatuk kering. Keluhan berat badan menurun dapat dikaitkan dengan neoplasma dan tuberkulosis, batuk berdarah dikaitkan dengan neoplasma, emboli paru dan tuberkulosa yang berat. Demam subfebris pada tuberkulosis, demam menggigil pada empiema, ascites pada sirosis hepatis.

Berdasarkan hasil pengkajian, dari ketiga pasien semuanya mengeluh sesak nafas. Rentang pernafasan pasien adalah 28 32 kali/menit. NANDA (2018) mengungkapkan masalah keperawatan yang umum terjadi pada penderita sesak nafas yaitu salah satunya pola napas tidak efektif dan gangguan pertukaran gas. Pola napas tidak efektif diakibatkan oleh terganggunya ekspansi paru akibat akumulasi cairan sehingga akan menimbulkan manifestasi klinis seperti peningkatan frekuensi napas, kesulitas bernapas (dipsnea), penggunaan otot-otot bantu pernapasan, dan kasus-kasus berat muncul seperti sianosis.

Intervensi keperawatan yang bisa dilakukan untuk mengurangi masalah sesak nafas salah satunya adalah dengan positioning. Hal ini bertujuan untuk meningkatkan ekspansi paru sehingga mengurangi sesak (Dean, 2014). Pemilihan posisi untuk penderita dengan masalah pernapasan sangat penting untuk memfasilitasi pernapasan yang adekuat. Terdapat berbagai macam posisi tidur mulai dari supine, lateral dan fowler. Posisi fowler merupakan posisi pilihan untuk orang yang mengalami kesulitan pernapasan (Kozier, 2010).
Menurut penelitian Najafi, et all (2018) tentang "The Effect of Position Change on Arterial Oxygen Saturation in Cardiac and Respiratory Patients: A Randomised Clinical Trial'. Hasil penelitian ini menunjukkan persentase saturasi oksigen rata-rata memiliki perbedaan yang signifikan secara statistik pada posisi semi fowler dibandingkan dengan posisi pronasi dan supinasi $(\mathrm{p}=0,016)$. Ditemukan juga bahwa ada perbedaan yang signifikan antara saturasi oksigen rata-rata pada tiga titik berbeda yaitu ujung jari, daun telinga dan ujung jari kaki yang lebih besar $(\mathrm{p}<0,001)$.

Pada posisi low fowler, posisi semi fowler dan posisi high fowler menunjukkan peningkatan posisi badan condong kedepan dapat meningkatkan fungsi ventilasi paru. Peningkatan ventilasi paru ini disebabkan oleh posisi badan yang condong kedepan atau keatas mengakibatkan organ abdominal tidak menekan diafrgama sesuai dengan tingkat kenaikan posisi fowler. Dari hasil wawancara dengan ketiga pasien, di dapatkan data bahwa posisi tidur setengah duduk atau semi fowler dapat membantu mengurangi keadaan sesak nafasnya dari pada posisi tidur terlentang atau supinasi. Akan tetapi, posisi semi fowler dianggap masih kurang nyaman karena menimbulkan sensasi nyeri pada lokasi pemasangan CTT dan pigtail.

Posisi high fowler adalah posisi duduk dimana kepala di tinggikan paling sedikit $60-90^{\circ}$. Kemiringan menggunakan gravitasi membantu mengembangkan dada dan mengurangi tekanan abdomen dan diafragma. Pada saat gravitasi terjadi akan menarik diafragma ke bawah serta memungkinkan ekspansi dada dan ventilasi paru yang lebih besar. Posisi ini dibantu penopang sandaran yang sering digunakan dua bantal yang diletakkan di punggung dan kepala (Kozier dkk, 2011).

Berdasarkan hasil observasi terdapat perubahan nilai pernafasan dan saturasi oksigen sebelum dan sesudah dilakukan posisi high fowler oleh perawat diruangan. Penilaian sebelum posisi high fowler dilakukan dengan posisi standar diruangan 
pada kasus pasien dengan efusi pleura dengan menggunakan posisi semi fowler. Pengukuran nilai pernafasan dan saturasi oksigen adalah selama satu menit. Kemudian setelah dilakukan posisi high fowler selama 30 menit, peneliti kembali lagi melakukan pengukuran nilai pernafasan dan saturasi oksigen selama satu menit.

Rentang nilai pernafasan pasien sebelum posisi high fowler pada hari pertama adalah 26 - 30 kali permenit dengan nilai saturasi oksigen $96-98 \%$. Sedangkan setelah dilakukan posi high fowler selama 30 menit, rentang nilai frekuensi pernafasan $22-27$ kali permenit dan nilai saturasi oksigen 97 98\%. Rentang nilai pernafasan pasien sebelum posisi high fowler pada hari kedua adalah 26 - 28 kali permenit dengan nilai saturasi oksigen $97-98 \%$. Sedangkan setelah dilakukan posi high fowler selama 30 menit, rentang nilai frekuensi pernafasan $22-25$ kali permenit dan nilai saturasi oksigen 98 99\%. Rentang nilai pernafasan pasien sebelum posisi high fowler pada hari ketiga adalah 24 - 28 kali permenit dengan nilai saturasi oksigen $98-99 \%$. Sedangkan setelah dilakukan posi high fowler selama 30 menit, rentang nilai frekuensi pernafasan $22-24$ kali permenit dan nilai saturasi oksigen 98 $99 \%$.

Hasil studi kasus ini sejalan dengan penelitian Meilirianta, Tohri dan Suhendra (2010) tentang posisi semi-fowler dan posisi high fowler terhadap perubahan saturasi oksigen pada pasien asma bronkial di Ruang rawat inap D3 dan E3 Rumah Sakit Umum Daerah Cibabat Cimahi. Hasil penelitian ini menunjukkan bahwa Rerata perubahan saturasi oksigen setelah dilakukan posisi semi-fowler sebesar 93.20 sedangkan pada posisi high fowler sebesar 94.60. Berdasarkan uji paired t-test diperoleh angka signifikan yaitu $P=0.001$. Artinya Posisi High fowler lebih efektif dalam meningkatkan perubahan saturasi dan mengurangi sesak nafas dibandingkan semi fowler.

Hasil studi kasus ini berbanding terbalik dengan penelitian yang di lakukan
Ritianingsih tentang Pengaruh Posisi Duduk High Fowler dan Orthopneic Terhadap Fungsi Ventilasi Paru Pada Asuhan Keperawatan Pasien PPOK di Rs Paru Dr. M. Goenawan Partowidigdo Bogor yang bertujuan untuk menjelaskan perbedaan pengaruh posisi duduk high fowler dan orthopneic terhadap fungsi ventilasi paru pada asuhan keperawatan pasien PPOK di RS Paru Dr. M. Goenawan Partowidigdo Bogor. Metode penelitian yang digunakan adalah Quasi eksperimen, Pre \& post test pada 36 orang pasien PPOK yang dirawat di RS Paru Dr.Goenawan Partowidigdo Cisarua Bogor yang diambil secara purposive sampling. Hasil penelitian ini menunjukkan bahwa frekuensi nafas memiliki nilai yang sama. Posisi high fowler dan orthopneic dapat meningkatkan nilai APE ( $\mathrm{p}=0,0005)$, tetapi posisi orthopneic dapat meningkatkan nilai APE lebih baik dibandingkan high fowler $(\mathrm{p}=0,0005)$. Usia berhubungan terhadap peningkatan nilai APE pasien PPOK baik pada posisi high fowler $(\mathrm{p}=0,0048)$ maupun pada orthopneic $(\mathrm{p}=0,0005)$. Tinggi badan, berat badan, dan jenis kelamin tidak mempengaruhi fungsi ventilasi paru baik pada posisi high fowler maupun orthopneic.

Penelitian lain yang dilakukan Annisa, Utomo, \& Utami (2015), pada posisi telentang individu mengalami dua proses fisiologi yang dapat menekan pernafasan yaitu peningkatan volume darah dalam rongga toraks dan kompresi dada. Akibatnya, proses pertukaran udara pada seseorang yang berbaring telentang tidak berlangsung secara maksimal. Sedangkan pada posisi semi fowler ini menunjukkan peningkatan posisi badan condong kedepan yang dapat meningkatkan fungsi ventilasi paru. Posisi badan yang condong kedepan atau keatas inilah yang mengakibatkan organ abdominal tidak menekan diafrgama sesuai dengan tingkat kenaikan posisi fowler. Sehingga dengan posisi fowler inilah pasien akan merasakan nyaman saat bernapas.

Terdapat perbedaaan peningkatan saturasi oksigen pada ketiga pasien. Pada Tn. F saturasi awalnya 97\% setelah diberi posisi 
high folwer naik menjadi $98 \%$, sehingga didapatkan kenaikan sebesar 1\%. Sedangkan pada Ny. W dan Ny.K saturasi awalnya $97 \%$ setelah diberi posisi high fowler naik menjadi $99 \%$, sehingga didapatkan kenaikan sebesar 2 $\%$. Perbedaan kenaikan ini disebabkan karena kadar Hemoglobin $(\mathrm{Hb})$ dalam darah yang berbeda, pada Tn. F kadar Hbnya rendah yaitu 8,5 g/dl sedangkan pada Ny.K kadar Hbnya normal yaitu 14,5 g/dl. Kadar Hb yang rendah inilah dapat mengurangi pasokan oksigen yang sampai ke jaringan.

Penurunan nilai status pernafasan dan saturasi oksigen setelah positioning high fowler bisa juga di pengaruhi oleh pemberian oksigen. Dari hasil studi kasus di dapatkan data bahwa semua pasien diberikan oksigen 2 liter/menit dengan menggunakan nasal canule. Terapi oksigen merupakan suatu intervensi medis berupa upaya pengobatan dengan pemberian oksigen untuk mencegah atau memerbaiki hipoksia jaringan dan mempertahankan oksigenasi jaringan agar tetap adekuat dengan cara meningkatkan masukan oksigen ke dalam sistem respirasi, meningkatkan daya angkut oksigen ke dalam sirkulasi dan meningkatkan pelepasan atau ekstraksi oksigen ke jaringan (Widiyanto, 2014). Selain itu, terapy pemberian obat juga memungkinkan untuk mengurangi sesak nafas. Semua pasien mendapatkan therapy codein dan $\mathrm{N}$ asetilsistein untuk menguragi gejala batuk dan mengencerkan dahak yang menghalangi saluran pernafasan.

\section{Simpulan}

Posisi high fowler merupakan posisi pilihan untuk pasien yang mengalami sesak nafas khususnya pada pasien yang mengalami efusi pleura. Berdasarkan hasil observasi selama tiga hari, terdapat perubahan nilai pernafasan dan saturasi oksigen sebelum dan sesudah dilakukan posisi high fowler oleh perawat diruangan. Penilaian sebelum posisi high fowler dilakukan dengan posisi standar diruangan pada kasus pasien dengan efusi pleura dengan menggunakan posisi semi fowler. a. Rentang nilai pernafasan pasien sebelum posisi high fowler pada hari pertama adalah 26 - 30 kali permenit dengan nilai saturasi oksigen 96 - 98\%. Sedangkan setelah dilakukan posi high fowler selama 30 menit, rentang nilai frekuensi pernafasan $22-27$ kali permenit dan nilai saturasi oksigen $97-98 \%$.

b. Rentang nilai pernafasan pasien sebelum posisi high fowler pada hari kedua adalah 26 - 28 kali permenit dengan nilai saturasi oksigen 97 - 98\%. Sedangkan setelah dilakukan posi high fowler selama 30 menit, rentang nilai frekuensi pernafasan $22-25$ kali permenit dan nilai saturasi oksigen $98-99 \%$.

c. Rentang nilai pernafasan pasien sebelum posisi high fowler pada hari ketiga adalah 24 - 28 kali permenit dengan nilai saturasi oksigen 98 - 99\%. Sedangkan setelah dilakukan posi high fowler selama 30 menit, rentang nilai frekuensi pernafasan 22 - 24 kali permenit dan nilai saturasi oksigen $98-99 \%$.

Hasil penelitian ini yaitu posisi high fowler dapat diaplikasikan perawat yang merawat pasien yang mengalami sesak nafas khususnya pada pasien yang mengalami efusi pleura.

\section{Referensi}

Annisa, Utomo, \& Utami. (2015). Pengaruh Perubahan Posisi Terhadap Pola Nafas Pada Pasien Gangguan Pernafasan. Program Studi Ilmu Keperawatan Universitas Riau. 292303

Dean, E. (2014).Effect of Body Position on Pulmonary Function. Journal of American Physical Therapy

Kozier, B., Erb, G., Berman, Audrey., Snyder, S. J. (2011) Buku ajar Fundamental Keperawatan, Konsep, Proses dan Praktik. Ed. 7.Vol. 1. Jakarta:EGC 
McGrath E, Anderson PB. (2011) Diagnosis of Pleural Effusion : a Systematic Approach. American Journal of Critical Care. Vol 20, No. 2.

Meilirianta, Tohri. T \& Suhendra (2010). Posisi Semi-Fowler Dan Posisi High Fowler Terhadap Perubahan Saturasi Oksigen Pada Pasien Asma Bronkial Di Ruang Rawat Inap D3 Dan E3 Rumah Sakit Umum Daerah Cibabat Cimahi.

Moaty, A. M. A,Mokadem, N. M dan Elhy, A. H.A. (2017). Effect of Semifowler's Positions on Oxygenation and Hemodynamic Status among Critically III Patients With Traumatic Brain Injur. International Journal of Novel Research in Healthcare and Nursing. Vol 4, Issu 2

Najafi, S., Dehkordi, S. M., \& Basirimoghaddam, M. (2018). The Effect Of Position Change On Arterial Oxygen Saturation In Cardiac And Respiratory Patients : A Randomised Clinical Trial. 33-37.

Nanda. (2018). Diagnosis Keperawatan Definisi \& Klasifikasi 2018-2020 Edisi 11 editor T Heather Herdman, Shigemi Kamitsuru. Jakarta: EGC.

Nasution \& Widirahardjo. (2018). Perubahan Faal Paru pada Penderita Efusi Pleura setelah Tindakan Aspirasi Cairan Pleura. Majalah Kedokteran Nusantara. Vol 51 No 1 Maret 2018

Nursalam. (2014). Metodologi Penelitian Ilmu Keperawatan : Pendekatan Praktis, Edisi 3. Jakarta : Salemba Medika

Puspita, Soleha, \& Berta, 2015. Penyebab Efusi Pleura di Kota Metro pada tahun 2015. Journal ArgoMedicine. Universitas Lampung.

Safitri, R. \& Andriyani, A. (2011).Keefektifan Pemberian Posisi Semi Fowler Terhdap Penurunan Sesak Nafas Pada Pasien Asma Di Ruang Rawat Inap Kelas III RSUD Dr. Moewardi Surakarta.Prodi S1 keperawatan Sekolah Tinggi Ilmu Kesehatan Aisyiyah Surakarta. Vol. 8, No. 2 Agustus 2011.

WHO,(2017).Monitoring Health For The SDGs, Sustainable Development Goals. ISBN 978-92-4-156548-6

Widiyanto B, Yasmin LS. (2014). Terapi Oksigen terhadap Perubahan Saturasi Oksigen melalui Pemeriksaan Oksimetri pada Pasien Infark Miokard Akut (IM-A). Prosiding Konferensi Nasional II PPNI Jawa Tengah. 1(1): 138-43. 